\title{
PENGARUH UKURAN PERUSAHAAN, PROFITABILITAS PERUSAHAAN, SOLVABILITAS PERUSAHAAN DAN LIKUIDITAS PERUSAHAAN TERHADAP PENUNDAAN AUDIT PADA PERUSAHAAN CONSUMER GOODS YANG TERDAFTAR DI BURSA EFEK INDONESIA
}

\author{
Nikita Melisa Rattu \\ David Paul Elia Saerang \\ Grace Nangoi
}

Nikitarattu@ymail.com

\begin{abstract}
Presentation of information can be useful when presented accurately and timely when needed by users of financial statements. Audit report is financial statetements audited by the auditor. The information contained in the financial statements referred helpful if presented accurately and timely, which is available when needed by the users of financial statements, such as creditors, investors, governments, communities and other parties as a basis for making a decision .

The data used are secondary data, the financial statements of nine companies from food and beverage sub-sectors listed in Indonesia Stock Exchange in 2010-2013. To prove the hypothesis, used multiple regression testing

partial test concluded that the profitability, solvency, Company Size and Liquidity not significantly affect audit delay in the sub-sector firms in the food and beverage IDX. Simultaneous testing concluded that the profitability, solvency, Company Size and Liquidity simultaneously no significant effect on the Audit Delay companies sector food and beverage sub IDX
\end{abstract}

\section{Keywords: Audit delay, Company Size, Profitability, Liquidity Company, Company Solvency}

\section{PENDAHULUAN}

\subsection{Latar Belakang}

Semakin berkembangnya dunia usaha di Indonesia menyebabkan perusahaan-perusahaan besar membutuhkan sumber pendanaan dari luar. Salah satu sumber tersebut adalah penerbitan saham kepada masyarakat luas, yang disebut dengan go public. Perusahaan go public wajib menerbitkan laporan keuangan pada setiap akhir periode akuntansi sebagai bentuk pertanggungjawaban kepada masyarakat, khususnya investor dan calon investor.

Penyajian informasi keuangan dapat bermanfaat bilamana disajikan secara akurat dan tepat waktu pada saat dibutuhkan oleh pemakai laporan keuangan. Laporan auditan adalah laporan keuangan yang telah di audit oleh auditor. Nilai dan ketepatan waktu pelaporan keuangan merupakan faktor penting bagi kemanfaatan laporan keuangan. Laporan keuangan tersebut terdiri dari neraca, laporan laba rugi, laporan arus kas, laporan perubahan ekuitas dan catatan atas laporan keuangan. Ketepatan waktu ini terkait dengan manfaat dari laporan keuangan itu sendiri dan merupakan unsur penting dalam pengambilan keputusan investasi. Karakteristik kualitatif merupakan ciri khas yang membuat informasi dalam laporan keuangan berguna bagi pengguna.Terdapat empat karakteristik kualitatif pokok yaitu : dapat dipahami, relevan, keandalan, dan dapat diperbandingkan.

Informasi yang terkandung dalam laporan keuangan disebut bermanfaat jika disajikan secara akurat dan tepat waktu, yakni tersedia saat dibutuhkan oleh.para pengguna laporan keuangan, seperti kreditor, investor, pemerintah, masyarakat dan pihak-pihak lain sebagai dasar pengambilan suatu keputusan.Menurut Givoly dan Palmon (2000:Vol VII No 3) dalam Aryati (2005), nilai dari ketepatwaktuan pelaporan keuangan merupakan faktor penting bagi kemanfaatan laporan keuangantersebut. Sementara Halim (2000) menyebutkan bahwa ketepatan waktu penyajianlaporan keuangan dan laporan audit (timeliness) menjadi prasyarat utama bagipeningkatan harga saham perusahaan tersebut...

Ketertundaan laporan keuangan ini dapat berdampak negatif pada reaksi pasar. Makin lama masa tunda, maka relevansi laporan keuangan makin diragukan. Chambers dan Penman (2001) dalam Subekti (2004) menunjukkan bahwapengumuman laba yang terlambat menyebabkan abnormal returns negatif 
sedangkanpengumuman laba yang lebih cepat menunjukkan hasil sebaliknya. Hal ini terjadidikarenakan investor pada umumnya menganggap keterlambatan pelaporan keuangan merupakan pertanda buruk bagi kondisi kesehatan perusahaan

Makin lama auditor menyelesaikan pekerjaan auditnya, semakin lama pula audit delay. Namun bisa jadi auditor memperpanjang masa auditnya dengan menunda penyelesaian audit laporan keuangan karena alasan tertentu, semisal pemenuhan standar untuk meningkatkan kualitas audit oleh auditor yang akhirnya menuntut waktu lebih lama Sebagaimana tercantum dalam Standar Profesional Akuntan Publik (SPAP) dari Ikatan Akuntan Indonesia (IAI) tentang Standar Pekerjaan Lapangan yang mengatur prosedur dalam penyelesaian pekerjaan lapangan bagi auditor, bahwa auditor perlu memiliki perencanaan atas aktivitas yang akan dilakukan. Juga perlu pemahaman yang memadai atas struktur pengendalian internal, diikuti dengan pengumpulanbukti-bukti kompeten yang diperoleh melalui inspeksi, pengamatan, pengajuanpertanyaan, dan konfirmasi sebagai dasar dalam menyatakan pendapat atas laporan keuangan.

\subsection{Rumusan Masalah}

Berdasarkan uraian sebelumnya, maka perumusan masalahnya adalah sebagai berikut

1. Apakah ukuran perusahaan berpengaruh terhadap audit delay?

2. Apakah profitabilitas perusahaan berpengaruh terhadap audit delay?

3. Apakah solvabilitas perusahaan berpengaruh terhadap audit delay?

4. Apakah likuiditas perusahaan berpengaruh terhadap audit delay?

5. Apakah ukuran perusahaan, profitabilitas perusahaan, solvabilitas perusahaan, dan likuiditas perusahaan berpengaruh terhadap audit delay?

\subsection{Tujuan Penelitian}

Sesuai dengan latar belakang dan rumusan masalah , maka yang menjadi tujuan dalam penelitian ini adalah sebagai berikut :

1. Untuk menganalisis pengaruh ukuran perusahaan berpengaruh terhadap audit delay.

2. Untuk menganalisis pengaruh profitabilitas perusahaan berpengaruh terhadap audit delay.

3. Untuk menganalisis pengaruh solvabilitas perusahaan berpengaruh terhadap audit delay.

4. Untuk menganalisis pengaruh likuiditas perusahaan berpengaruh terhadap audit delay.

5. Untuk menganalisis pengaruh ukuran perusahaan, profitabilitas perusahaan, solvabilitas perusahaan, dan likuiditas perusahaan berpengaruh terhadap audit delay.

\subsection{Manfaat Penelitian}

Manfaat dari penelitian ini dapat dijabarkan sebagai berikut:

1. Membantu auditor dalam mengidentifikasi faktor-faktor yang mempengaruhi audit delay sehingga dapat mengoptimalkan kinerja yang berimbas pada tepatnya waktu pelaporan keuangan

2. Memberi deskripsi tentang faktor-faktor yang mempengaruhi audit delay di Indonesia, dimana bukti empiris tersebut dapat dijadikan tambahan wawasan dalam penelitian berikutnya.

3. Hasil penelitian dapat dijadikan pedoman dalam melakukan pekerjaan audit sehingga mempersingkat rentang waktu audit; meningkatkan efisiensi dan efektivitas dengan mencermati faktor-faktor yang dominan mempengaruhi audit delay

\section{KERANGKA TEORITIS}

\subsection{Grand Theory : Teori Pengambilan Keputusan}

Proses pengambilan keputusan diawali dengan adanya kebutuhan yang berusaha untuk dipenuhi. Pemenuhan kebutuhan ini terkait dengan beberapa alternatif sehingga perlu dilakukan evaluasi yang bertujuan untuk memperoleh alternatif terbaik dari persepsi konsumen. Di dalam proses membandingkan ini konsumen memerlukan informasi yang jumlah dan tingkat kepentingannya tergantung dari kebutuhan konsumen serta situasi yang dihadapinya

Pengertian Pengambilan Keputusan dikemukakan oleh :

a. Ralp C. Davis;

b. Mary Follet;

c. James A.F. Stoner 


\subsection{Definisi Audit}

Definisi audit (auditing) menurut Messier (2003:8) adalah suatu proses sistematis mendapatkan dan mengevaluasi bukti-bukti secara objektif sehubungan dengan asersi atas tindakan dan peristiwa ekonomi untuk memastikan tingkat kesesuaian antara asersi-asersi tersebut dan menetapkan kriteria serta mengkomunikasikan hasilnya kepada pihak-pihak yang berkepentingan

Secara umum definisi pemeriksaan menurut Mulyadi (2002:9) dalam bukunya Auditing adalah sebagai berikut :"Auditing adalah suatu proses sistematik untuk memperoleh dan mengevaluasi bukti secara objektif mengenai pernyataan-pernyataan tentang kegiatan dan kejadian ekonomi, dengan tujuan untuk menetapkan tingkat kesesuaian antara pernyataan-pernyataan tersebut dengan kriteria yang telah ditetapkan, serta penyampaian hasil-hasilnya kepada pemakai yang berkepentingan

\subsection{Jenis-Jenis Pemeriksaan}

Jenis-jenis pemeriksaan menurut Sukrisno Agoes (2004:9) dalam bukunya Auditing (Pemeriksaan Akuntan) oleh Kantor Akuntan Publik adalah sebagai berikut :

Ditinjau dari luasnya pemeriksaan, audit bisa dibedakan atas :

1. General Audit (Pemeriksaan Umum)

2. Special Audit (Pemeriksaan Khusus)".

\subsection{Tujuan Audit}

Menurut Ikatan Akuntan Indonesia (2001), tujuan audit atas laporan keuangan oleh auditor independen pada umumnya adalah untuk menyatakan pendapat tentang kewajaran dalam semua hal yang material, posisi keuangan, hasil usaha, perubahan ekuitas dan arus kas sesuai dengan prinsip akuntansi yang berlaku umum di Indonesia

Kewajaran laporan keuangan dinilai berdasarkan asersi yang terkandung dalam setiap unsur yang disajikan dalam laporan keuangan. Dalam menghasilkan jasa audit, auditor memberikan keyakinan atas asersi yang dibuat oleh manajemen dalam laporan keuangan historis.

\subsection{Standar Auditing}

Standar auditing yang telah ditetapkan dan disahkan oleh Institut Akuntan Publik Indonesia (2011:150.1-150.2) dalam Sukrisno Agoes (2012:31),terdiri dari sepuluh standar yang dikelompokkan menjadi tiga kelompok besar yakni Standar Umum, Standar Pekerjaan Lapangan, Standar Pelaporan

\subsection{Laporan Keuangan}

Laporan keuangan merupakan laporan yang disusun secara sistematis tentang kinerja dan posisi keuangan suatu lembaga/organisasi/ perusahaan dalam suatu periode tertentu. Ini menunjukan bahwa laporan keuangan dapat dijadikan acuan untuk menilai kinerja lembaga yang menerbitkan laporan tersebut, dan kemampuan keuangan suatu organisasi/perusahaan. Informasi yang ada dalam laporan keuangan bersifat umum, tidak sepenuhnya dapat memenuhi kebutuhan informasi setiap pemakai, namun informasi yang disajikan masih dalam kategori memadai untuk pengambilan kebijkan ( Mursydi 2010:23 ).Konsep pengungkapan yang umumnya diusulkan adalah pengungkapan yang cukup (adequate), wajar (fair), dan lengkap (full).

\subsection{Audit Delay ( Penundaan Audit )}

Audit Delay adalah lamanya waktu penyelesaian audit yang diukur dari tanggal penutupan tahun buku, hingga tanggal diselesaikannya laporan audit independen (Wiwik Utami, 2006:4)

Audit delay didefinisikan sebagai lamanya waktu penyelesaian audit yang diukur dari tanggal penutupan tahun buku hingga tanggal diterbitkannya laporan audit (Halim, 2000:46). MenurutLawrence dan Briyan (1988) dalam Yugo Trianto (2006:31) Audit Delay adalah lamanya hari yang dibutuhkan auditor untuk menyelesaikan pekerjaan auditnya, yang diukur dari tanggal penutupan tahunbuku hingga tanggal diterbitkannya laporan keuangan audit

Diungkap dalam penelitian Subekti dan Widiyanti (2004), perbedaan waktu yang sering dinamai dengan audit delay adalah perbedaan antara tanggal laporan keuangan dengan tanggal opini audit dalam laporan keuangan yang mengindikasikan tentang lamanya waktu penyelesaian audit yang dilakukan oleh auditor. Maka semakin panjang audit delay semakin lama auditor dalam menyelesaikan pekerjaan auditnya.

\section{KERANGKA KONSEPTUAL}


3.1 Kerangka Konseptual

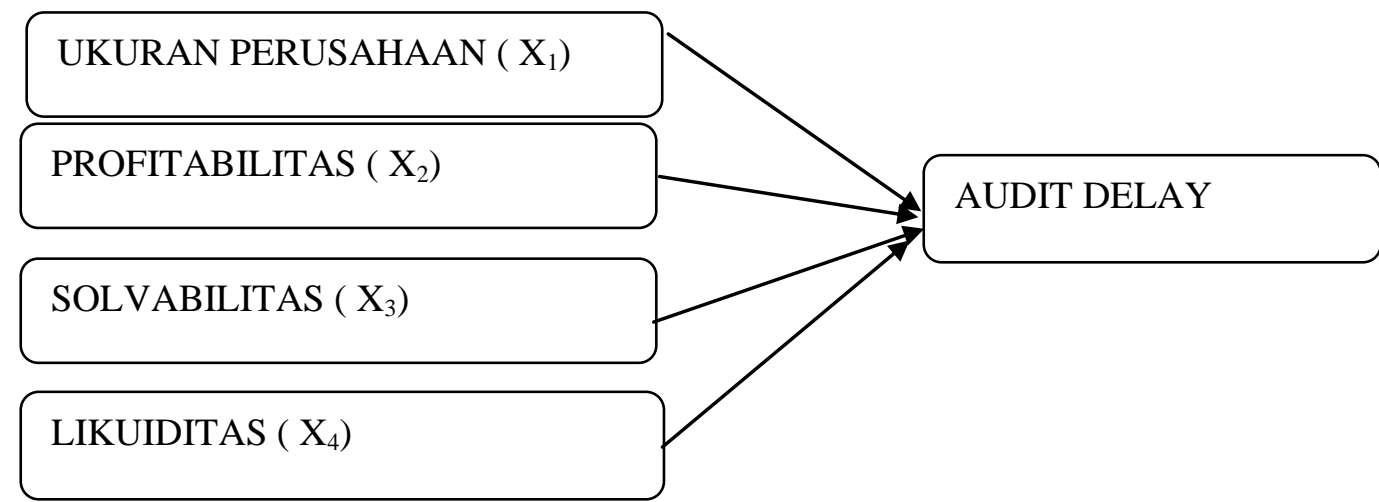

\subsection{Hipotesis}

Hipotesis dalam penelitian ini adalah sebagai berikut :

1. Diduga Ukuran perusahaan secara parsial berpengaruh terhadap Audit Delay.

Ha : X1 $\neq 0$

2. Diduga Profitabilitas secara parsial berpengaruh terhadap Audit Delay.

$\mathrm{Ha}: \mathrm{X} 2 \neq 0$

3. Diduga Solvabilitas secara parsial berpengaruh terhadap Audit Delay.

Ha : $\mathrm{X} 3 \neq 0$

4. Diduga Likuiditas secara parsial berpengaruh terhadap Audit Delay.

$\mathrm{Ha}: \mathrm{X} 4 \neq 0$

5. Diduga Ukuran perusahaan, Profitabilitas, Solvabilitas dan Likuiditas secara simultan berpengaruh terhadap Audit Delay.

$\mathrm{Ha}: \mathrm{X} 1, \mathrm{X} 2, \mathrm{X} 3, \mathrm{X} 4 \neq 0$

\section{Metode Penelitian}

\subsection{Populasi dan Sampel}

Populasi dalam penelitian ini meliputi perusahaan-perusahaan yang terdaftar di Bursa efek indonesia khususnya Sub sektor makanan dan Minuman. Dalam penelitian ini diambil sampel 9 perusahaan dari 19 perusahaan sub sektoor makanan dan minuman yang terdaftar di bursa efek Indonesia dengan tahun penelitian 2010,2011,2012,2013,2014

\subsection{Jenis dan Sumber Data}

Penelitian ini membutuhkan data sekunder berupa laporan keuangan perusahaan-perusahaan yang terdaftar di Bursa Efek Indonesia. Laporan keuangan tersebut disyaratkan telah diaudit dengan tahun terbit 2010, 2011, 2012, dan 2013

\subsection{Metode Pengumpulan Data}

Metode pengumpulan data menggunakan teknik dokumentasi, yaitu dengan melihat dokumen yang sudah terjadi (laporan keuangan dan laporan audit perusahaan). Laporan keuangan auditan perusahaan diperoleh dari akses website Bursa Efek Indonesia (www.idx.co.id)

\subsection{Metode Analisis}

Pada penelitian ini, pengujian dilakukan dengan analisis regresi linier berganda, yaitu suatu metode statistik yang umum digunakan untuk meneliti hubungan antara sebuah variabel dependen dengan beberapa variabel independen.

Adapun model regresi yang digunakan adalah sebagai berikut:

Keterangan :

$$
\text { AUDELAY }=\beta_{0}+\beta_{1} \text { SIZE }+\beta_{2} \text { PROF }+\beta_{3} \text { SOLV }+B_{4} \text { LIK }+\varepsilon
$$

$\begin{array}{lll}\text { AUDELAY } & = & \begin{array}{l}\text { jangka waktu tanggal penutupan tahun buku dengan Tanggal opini } \\ \text { Laporan keuangan auditor Independen }\end{array} \\ \text { SIZE } & = & \text { ukuran perusahaan } \\ \text { PROF } & = & \text { profitabilitas (net income to total asset) }\end{array}$




$\begin{array}{lll}\text { SOLV } & = & \text { solvabilitas (total debt to total asset) } \\ \text { LIK } & = & \text { Likuiditas curren ratio (aktiva lancar to hutang lancar) }\end{array}$

\subsection{Variabel Penelitian dan Definisi Operasional}

Dalam penelitian ini variabel dependen (Y ) adalah penundaan audit ( audit delay) sedangkan variabel independen $(X)$ adalah Ukuran Perusahaan $\left(X^{1}\right)$, Profitabilitas $\left(X^{2}\right)$, Solvabilitas $\left(X^{3}\right)$, dan likuiditas ( $\mathrm{X}^{4}$ )

Definisi operasional dan pengukuran untuk variabel-variabel tersebut adalah

Penundaan Audit / Audit Delay (Y)

Dalam penelitian ini, variabel dependennya adalah penundaan audit /audit delay yang diukur secara kuantitatif dalam jumlah hari, ialah jangka waktu antara tanggal penutupan tahun buku hingga tanggal yang tertera pada laporan auditor independen. Sebagai contoh, laporan keuangan perusahaan periode 2005 dengan tanggal tutup buku 31 Desember 2005 mempunyai laporan auditor dengan tanggal 21 Maret 2006.Dengan demikian audit delay pada perusahaan tersebut sebesar 80 hari Ukuran Perusahaan / SIZE $\left(\mathrm{X}^{1}\right)$

Ukuran Perusahaan dapat diklasifikasikan dalam berbagai cara. Dalam penelitian ini, ukuran perusahaan dihitung dengan menggunakan total asset yang dimiliki perusahaan. Ukuran perusahaan diproksikan dengan nilai logaritma untukmenghaluskan besarnya angka dan menyamakan ukuran saat regresi.Ukuran Perusahaan $=\mathrm{t} \log$ (total asset)

Profitabilitas / PROFT $\left(\mathrm{X}^{2}\right)$

Profitabilitas diukur dari net income dibagi dengan total asset. Perusahaan dengan tingkat profitabilitas tinggi diduga membutuhkan waktu lebih pendek guna menyelesaikann audit.

\section{$R O A$}

Net Income

Solvabilitas / SOLV ( $\left.\mathrm{X}^{3}\right)$

$$
=\frac{\text { Net Income }}{\text { Total Assets }} \times 100 \%
$$

Solvabilitas diukur menggunakan rasio DER yaitu rasio perbandingan antara nilai total debt dengan nilai total modal sendiri. Menurut Kasmir (2012:157), "DER berguna untuk mengetahui jumlah dana yang disediakan peminjam (kreditur) dengan pemilik perusahaan." Dengan kata lain, rasio ini berfungsi untuk mengetahui setiap rupiah modal sendiri yang dijadikan untuk jaminan utang." Menurut Kasmir (2012:158) secara matematis DER dapat dihitung dengan menggunakan rumus :

\section{$D E R$}

Total Hutang

Likuiditas /LIK $\left(\mathrm{X}^{4}\right)$

$$
=\frac{T}{\text { Total Equity }} \times 100 \%
$$

Likuiditas diukur menggunakan rasio Current Ratio yaitu rasio perbandingan antara nilai aktiva lancar dengan nilai hutang lancar

HASIL ANALISIS DAN PEMBAHASAN

Uji Normalitas

Uji Normalitas Data

One-Sample Kolmogorov-Smirnov Test

\begin{tabular}{|ll|r|r|r|}
\hline & & & \multicolumn{2}{c|}{$\begin{array}{c}\text { Ukuran } \\
\end{array}$} \\
& & Profitabilitas & \multicolumn{1}{c|}{ Solvabilitas } & \multicolumn{1}{c|}{ Perusahaan } \\
\hline $\mathrm{N}$ & Mean & 45 & 45 & 45 \\
Normal & Std. Deviation & 1.9668 & -.1405 & 2.6555 \\
Parameters & .24908 & .29606 & .12282 \\
Most Extreme & Absolute & .172 & .118 & .141 \\
Differences & Positive & .097 & .118 & .080 \\
& Negative & -.172 & -.111 & -.141 \\
Kolmogorov-Smirnov Z & 1.157 & .794 & .949 \\
Asymp. Sig. (2-tailed) & .137 & .555 & .329 \\
\hline
\end{tabular}

a. Test distribution is Normal.

b. Calculated from data. 
One-Sample Kolmogorov-Smirnov Test

\begin{tabular}{|c|c|c|c|}
\hline & & Likuiditas & Audit Delay \\
\hline $\mathrm{N}$ & & 45 & 45 \\
\hline \multirow{2}{*}{ Normal Parameters ${ }^{\mathrm{a}, \mathrm{b}}$} & Mean & 11.7779 & 84.0042 \\
\hline & Std. Deviation & 1.24707 & 14.00557 \\
\hline \multirow[t]{3}{*}{ Most Extreme Differences } & Absolute & .154 & .134 \\
\hline & Positive & .124 & .134 \\
\hline & Negative & -.154 & -.105 \\
\hline Kolmogorov-Smirnov Z & & 1.034 & .901 \\
\hline Asymp. Sig. (2-tailed) & & .235 & .392 \\
\hline
\end{tabular}

a. Test distribution is Normal.

b. Calculated from data.

Sumber : Data Diolah Penulis, 2015

Pada tabel dan gambar di atas menunjukkan hasil uji Normalitas data pada variable Profitabilitas dengan probabilitas signifikansi sebesar 0,137 >0,05, pada variable Solvabilitasdengan probabilitas signifikansi sebesar 0,555 >0,05, variable Ukuran Perusahaan dengan probabilitas signifikansi sebesar $0,329>0,05$, variable Likuiditas dengan probabilitas signifikansi sebesar 0,235 > 0,05 dan variable Audit Delay dengan probabilitas signifikansi sebesar 0,392>0,05 dan dapat dilihat bahwa penyebaran databerada pada sekitar garis diagonal dan mengikuti garis arah diagonal, maka nilairesidual terstandarisasi. Dengan demikian maka model regresi berganda memenuhiasumsi normalitas, berarti berdistribusi normal atau model telah memenuhi asumsi normalitas.

Uji Multikolineritas

\section{Uji Multikolineritas Coefficients $^{\mathbf{a}}$}

\begin{tabular}{|c|c|c|c|}
\hline \multirow{2}{*}{\multicolumn{2}{|c|}{ Model }} & \multicolumn{2}{|c|}{ Collinearity Statistics } \\
\hline & & \multirow[t]{2}{*}{ Tolerance } & VIF \\
\hline 1 & (Constant) & & \\
\hline & Profitabilitas & .828 & 1.208 \\
\hline & Solvabilitas & .569 & 1.757 \\
\hline & Ukuran Perusahaan & .724 & 1.381 \\
\hline & Likuiditas & .572 & 1.747 \\
\hline
\end{tabular}

a. Dependent Variable: Audit Delay

Sumber : Data Diolah Penulis, 2015

Hasil analisis pada Tabel di atas, diketahui bahwa keseluruhan variabel pada model regresi dengan dependen variabel Audit Delay besarnya nilai VIF tidak melibihi angka 1, dengan nilai Tolerance sebesar tidak melebihi angka 10.Dengan demikian, berdasarkan data hasil analisis pada Tabel dan ketentuan pengujian multikolinearitas tersebut, diketahui bahwa keseluruhan variabel pada model regresi dengan dependen variabel Audit Delay memiliki nilai VIF disekitar angka 1, dan nilai Tolerance dibawah/lebih kecil dari angka 1. Hal ini berarti, ketiga variabel bebas tidak terdapat gejala/problem multikolineritas.

Uji Auto Korelasi

Uji Auto Korelasi

Model Summary ${ }^{b}$

\begin{tabular}{|l|r|r|r|r|r|}
\hline Model & R & R Square & Adjusted R Square & $\begin{array}{c}\text { Std. Error of the } \\
\text { Estimate }\end{array}$ & Durbin-Watson \\
\hline 1 & $.496^{\mathrm{a}}$ & .246 & .171 & 12.75201 & 1.906 \\
\hline
\end{tabular}

a. Predictors: (Constant), Likuiditas, Profitabilitas, Ukuran Perusahaan, Solvabilitas

b. Dependent Variable: Audit Delay

Sumber : Data Diolah Penulis, 2015 
Dari hasil pengolahan SPSS 18.0 diperoleh nilai $D W$ sebesar 1,906 nilai ini akan dibandingkan dengan nilai tabel dengan nilai signifikansi 5\%, jumlah sampel 45 (n) dan jumlah variabel independen 4 $(\mathrm{k}=4)$, karena nilai $D W 1,906$ berada diatas batas bawah $(d L)$ 1.336dan batas atas $(d U)$ 1.720, maka dapat disimpulkan bahwa pengujian auto korelasi pada model regresi Audit Delay. tidak ada autokorelasi positif atau negatif, jadi dapat disimpulkan tidak terdapat autokorelasi

\section{Uji Heteroskedastisitas}

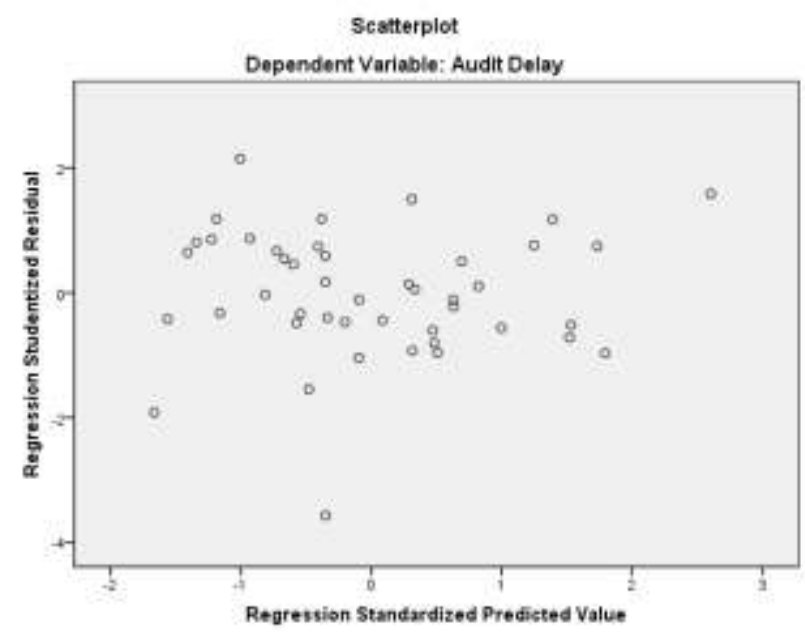

Dari hasil model regresi dengan dependen variabel Audit Delay pada gambar diatas scatterplots of residuals tidak membentuk pola tertentu (bergelombang, melebar kemudian menyempit, pola linear atau kuadratis), terlihat scatterplot Chart dalam Lampiran tidak membentuk pola tertentu, maka dalam regresi asumsi tidak terjadi heteroskedastisitas dipenuhi.

Analisis Regresi Berganda

\section{Hasil Analisis Regresi Linier Ganda} Coefficients $^{\mathrm{a}}$

\begin{tabular}{|c|c|c|c|c|c|}
\hline \multirow[t]{2}{*}{ Model } & \multicolumn{2}{|c|}{ Unstandardized Coefficients } & \multirow{2}{*}{$\frac{\text { Standardized Coefficients }}{\text { Beta }}$} & \multirow[b]{2}{*}{$\mathrm{t}$} & \multirow[b]{2}{*}{ Sig. } \\
\hline & $\mathrm{B}$ & Std. Error & & & \\
\hline 1 (Constant) & 29.257 & 43.112 & & .679 & .501 \\
\hline Profitabilitas & -21.729 & 8.483 & -.386 & -2.562 & .014 \\
\hline Solvabilitas & -18.297 & 8.607 & -.387 & -2.126 & .040 \\
\hline Ukuran Perusahaan & 54.117 & 18.391 & .475 & 2.943 & .005 \\
\hline Likuiditas & -4.143 & 2.038 & -.369 & -2.033 & .049 \\
\hline
\end{tabular}

a. Dependent Variable: Audit Delay

Sumber : Data Diolah Penulis, 2015

Berdasarkan hasil regresi linier ganda model 1, dependen variabel return on aset (ROA).Untuk membuat persamaan garis regresi dapat dilihat dari kolom B.

Constant $=29.257$

Profitabilitas $=-21.729$

Solvabilitas $=-18.297$

Ukuran Perusahaan $=54.117$

Likuiditas $=-4.143$

Berarti persamaan garis regresinya adalah:

$Y=29.257-21.729$ Profitabilitas-18.297 Solvabilitas + 54.117 Ukuran Perusahaan - 4.143 Likuiditas

1. Konstanta sebesar 29.257 menyatakan bahwa jika tidak ada Profitabilitas, Solvabilitas, Ukuran Perusahaan dan Likuiditas maka peningkatan Audit Delay adalah sebesar 29.257.

2. Koefisien $\mathrm{X} 1=-21.729$, menunjukkan bahwa Profitabilitas (X1) memiliki dampak negatif terhadap Audit Delay (Y). Artinya, jika Profitabilitas ditingkatkan sebesar satu satuan, maka peningkatan Audit Delay akan menurun sebesar -21.729. 
3. Koefisien $\mathrm{X} 2=-18.297$, menunjukkan bahwa Solvabilitas (X2) memiliki dampak negatif terhadap Audit Delay (Y). Artinya, jika Arus Solvabilitas ditingkatkan sebesar satu satuan, maka peningkatan Audit Delay akan menurun sebesar -18.297.

4. Koefisien X3 $=54.117$, menunjukkan bahwa Ukuran Perusahaan (X3) memiliki dampak positif terhadap Audit Delay (Y). Artinya, jika Arus Ukuran Perusahaan ditingkatkan sebesar satu satuan, maka peningkatan Audit Delay akan meningkat sebesar 54.117.

5. Koefisien $\mathrm{X} 4=-4.143$, menunjukkan bahwa Likuiditas (X4) memiliki dampak negatif terhadap Audit Delay (Y). Artinya, jika Likuiditas ditingkatkan sebesar satu satuan, maka peningkatan Audit Delay akan menurun sebesar -4.143.

6. Standar error (e) menunjukkan tingkat kesalahan pengganggu.

Hasil regresi linier berganda diatas menunjukkan bahwa variabel Ukuran Perusahaan memiliki pengaruh positif terhadap variabel Audit Delay. SedangkanProfitabilitas, Solvabilitas dan Likuiditas memiliki pengaruh negatif terhadap Audit Delay.

\section{Uji Hipotesis Secara Simultan (F)}

Menurut (Priyatno, 2011:258) uji F digunakan untuk menguji pengaruh semua variabel independen atau variabel bebas secara bersama-sama terhadap variabel dependen atau variabel terikat. Kriteria pengambilan keputusannya adalah bila $\mathrm{F}$ hitung $>\mathrm{F}$ tabel maka Ho ditolak dan menerima Ha (Ghozali, 2005,84).

Uji F digunakan untuk mengetahui pengaruh Profitabilitas, Solvabilitas, Ukuran Perusahaan dan Likuiditas secara bersama-sama terhadap audit delay .

Dasar pengambilan keputusan berdasarkan probabilitas :

a. Jika signifikansi $>0,05$, maka $\mathrm{H} 0$ diterima (terdapat pengaruh)

b. Jika signifikansi $<0,05$, maka Ha diterima (tidak terdapat pengaruh)

Hasil uji F dalam penelitian ini dapat dilihat pada tabel berikut ini :

Uji Hipotesis Secara Simultan

ANOVA $^{b}$

\begin{tabular}{|ll|r|r|r|r|r|}
\hline Model & & Sum of Squares & df & Mean Square & F & \multicolumn{1}{c|}{ Sig. } \\
\hline 1 & Regression & 2126.314 & 4 & 531.579 & 3.269 & $.021^{\mathrm{a}}$ \\
& Residual & 6504.548 & 40 & 162.614 & & \\
& Total & 8630.862 & 44 & & & \\
\hline
\end{tabular}

a. Predictors: (Constant), Likuiditas, Profitabilitas, Ukuran Perusahaan, Solvabilitas

b. Dependent Variable: Audit Delay

Sumber : Data Diolah Penulis, 2015

Berdasarkan data tabel diatas terlihat bahwa nilai $\mathrm{F}$ berada pada signifikansi 0,021 yang berarti < 0,05. maka $\mathrm{H}_{0}$ diterima dan $\mathrm{H}_{\mathrm{a}}$ ditolak sehingga dapat dikatakan bahwa $\mathrm{X}_{1}, \mathrm{X}_{2}, \mathrm{X}_{3}$, dan $\mathrm{X}_{4}$ berpengaruh terhadap Y.Dengan demikian secara bersama-sama Profitabilitas, Solvabilitas, Ukuran Perusahaan dan Likuiditasmemiliki pengaruh yang signifikan terhadap Audit Delay. Hipotesis yang diujikan yang menyatakan bahwa Profitabilitas, Solvabilitas, Ukuran Perusahaan dan Likuiditas berpengaruh positif dan nyata terhadap Audit Delay dapat diterima.

\subsubsection{Uji Hipotesis Secara Parsial (t)}

Kriteria pengambilan adalah bila tingkat signifikan $<0.05$ maka Ho ditolak dan menerima Ha.Langkahlangkah pengujiannya adalah sebagai berikut (Ghozali, 2005)

1. Menentukan Formulasi Hipotesis

a. Ha : $\beta=0$, artinya variabel $\mathrm{X} 1, \mathrm{X} 2, \mathrm{X} 3$ dan $\mathrm{X} 4$ tidak mempunyai pengaruh yang signifikan secara parsial terhadap variabel $\mathrm{Y}$.

b. H0 : $\beta=0$, artinya variabel $\mathrm{X} 1, \mathrm{X} 2, \mathrm{X} 3$ dan $\mathrm{X} 4$ mempunyai pengaruh yang signifikan secara parsial terhadap variabel $Y$.

2. Menentukan derajat kepercayaan $95 \%(\alpha=0,05)$

3. Menentukan signifikansi

a. Nilai signifikasi (P Value) $<0,05$ maka Ha ditolak dan $\mathrm{H} 0$ diterima. 
b. Nilai signifikasi (P Value) > 0,05 maka H0 ditolak dan Ha diterima.

Hasil uji t pada penelitian ini dapat dilihat ditabel berikut

Uji Hipotesis Parsial

Coefficients $^{\mathrm{a}}$

\begin{tabular}{|c|c|c|c|c|c|}
\hline \multirow[t]{2}{*}{ Model } & \multicolumn{2}{|c|}{ Unstandardized Coefficients } & \multirow{2}{*}{$\frac{\text { Standardized Coefficients }}{\text { Beta }}$} & \multirow[b]{2}{*}{$\mathrm{t}$} & \multirow[b]{2}{*}{ Sig. } \\
\hline & $\mathrm{B}$ & Std. Error & & & \\
\hline 1 (Constant) & 29.257 & 43.112 & & .679 & .501 \\
\hline Profitabilitas & -21.729 & 8.483 & -.386 & -2.562 & .014 \\
\hline Solvabilitas & -18.297 & 8.607 & -.387 & -2.126 & .040 \\
\hline Ukuran Perusahaan & 54.117 & 18.391 & .475 & 2.943 & .005 \\
\hline Likuiditas & -4.143 & 2.038 & -.369 & -2.033 & .049 \\
\hline
\end{tabular}

a. Dependent Variable: Audit Delay

Sumber : Data Diolah Penulis, 2015

Berdasarkan tabel diatas, maka hasil uji t pada penelitian ini dapat dijelaskan sebagai berikut:

1. Variabel (X1) Profitabilitas

Hipotesis variabel Profitabilitas adalah:

a. Ha : $\beta=0$, variabel (X1) Profitabilitas tidak mempunyai pengaruh yang signifikan secara parsial terhadap variabel Audit Delay.

b. H0 : $\beta=0$, variabel (X1) Profitabilitas mempunyai pengaruh yang signifikan secara parsial terhadap variabel Audit Delay.

Pada variabel Profitabilitas dengan tingkat signifikansi 95\% $(\alpha=0,05)$. Angka signifikansi (P Value) pada variabel Profitabilitas sebesar $0,014<0,05$. Dengan derajat kebebasan (df) $=n-2=45-2=$ 43 yaitu sebesar 2,017, di dengan demikian kriteria pengambilan keputusannya dikarenakan karena besarnya $t_{\text {hitung }}-2,562>t_{\text {tabel }} 2,017$, sehingga berarti secara parsial $X_{1}$ memiliki pengaruh terhadap $Y$. Atas dasar perbandingan tersebut, maka berarti Profitabilitas mempunyai pengaruh negatif namun signifikan terhadap Audit Delay.

2. Variabel (X2) Solvabilitas

Hipotesis variabel Solvabilitas adalah:

a. Ha : $\beta=0$, variabel (X1) Solvabilitas tidak mempunyai pengaruh yang signifikan secara parsial terhadap variabel Audit Delay.

b. H0 : $\beta=0$, variabel (X1) Solvabilitas mempunyai pengaruh yang signifikan secara parsial terhadap variabel Audit Delay.

Pada variabel Solvabilitas dengan tingkat signifikansi 95\% $(\alpha=0,05)$. Angka signifikansi (P Value) pada variabel Solvabilitas sebesar 0,040<0,05. Dengan derajat kebebasan (df) $=n-2=45-2=$ 43 yaitu sebesar 2,017, di dengan demikian kriteria pengambilan keputusannya dikarenakan karena besarnya $t_{\text {hitung }}-2,126>t_{\text {tabel }} 2,017$, sehingga berarti secara parsial $X_{1}$ memiliki pengaruh terhadap $Y$. Atas dasar perbandingan tersebut, maka berarti Solvabilitas mempunyai pengaruh negatif namun signifikan terhadap Audit Delay.

3. Variabel (X1) Ukuran Perusahaan

Hipotesis variabel Ukuran Perusahaan adalah:

c. Ha : $\beta=0$, variabel (X1) Ukuran Perusahaan tidak mempunyai pengaruh yang signifikan secara parsial terhadap variabel Audit Delay.

d. H0 : $\beta=0$, variabel (X1) Ukuran Perusahaan mempunyai pengaruh yang signifikan secara parsial terhadap variabel Audit Delay.

Pada variabel Ukuran Perusahaan dengan tingkat signifikansi 95\% $(\alpha=0,05)$. Angka signifikansi (P Value) pada variabel Ukuran Perusahaan sebesar 0,005<0,05. Dengan derajat kebebasan $(\mathrm{df})=\mathrm{n}-2=45-2=43$ yaitu sebesar 2,017, di dengan demikian kriteria pengambilan keputusannya dikarenakan karena besarnya $t_{\text {hitung }} 2,943>t_{\text {tabel }} 2,017$, sehingga berarti secara parsial $\mathrm{X}_{1}$ memiliki pengaruh terhadap $\mathrm{Y}$. Atas dasar perbandingan tersebut, maka berarti Ukuran Perusahaan mempunyai pengaruh negatif namun signifikan terhadap Audit delay

4. Variabel (X4) Likuiditas

Hipotesis variabel Likuiditas adalah: 
a. Ha : $\beta=0$, variabel (X1) Likuiditas tidak mempunyai pengaruh yang signifikan secara parsial terhadap variabel Audit Delay.

b. H0 : $\beta=0$, variabel (X1) Likuiditas mempunyai pengaruh yang signifikan secara parsial terhadap variabel Audit Delay.

Pada variabel Likuiditas dengan tingkat signifikansi 95\% $(\alpha=0,05)$. Angka signifikansi ( $\mathrm{P}$ Value) pada variabel Solvabilitas sebesar $0,049<0,05$. Dengan derajat kebebasan (df) $=n-2=45-2=$ 43 yaitu sebesar 2,017, di dengan demikian kriteria pengambilan keputusannya dikarenakan karena besarnya $t_{\text {hitung }}-2,126>t_{\text {tabel }} 2,017$, sehingga berarti secara parsial $X_{1}$ memiliki pengaruh terhadap $Y$. Atas dasar perbandingan tersebut, maka berarti Solvabilitas mempunyai pengaruh negatif namun signifikan terhadap Audit Delay

\subsection{Koefisien Determinasi}

\section{Hasil Uji Koefisien Determinasi} Model Summary ${ }^{\mathrm{b}}$

\begin{tabular}{|l|r|r|r|r|r|}
\hline Model & R & R Square & Adjusted R Square & $\begin{array}{c}\text { Std. Error of the } \\
\text { Estimate }\end{array}$ & Durbin-Watson \\
\hline 1 & $.496^{\mathrm{a}}$ & .246 & .171 & 12.75201 & 1.906 \\
\hline
\end{tabular}

a. Predictors: (Constant), Likuiditas, Profitabilitas, Ukuran Perusahaan, Solvabilitas

b. Dependent Variable: Audit Delay

Sumber : Data Diolah Penulis, 2015

Dengan melihat dari tabel diatas hasil perhitungan di atas di mana $\mathrm{R}$ square sebesar 0,246 atau 24,6\%. Hal ini menunjukkan besarnya kontribusi dari Profitabilitas, Solvabilitas, Ukuran Perusahaan dan Likuiditas terhadap Audit Delay sebesar 24,6\%sedangkan sisanya 75,4\% merupakan kontribusi faktor lain yang tidak diteliti dalam penelitian ini.

\section{KESIMPULAN DAN SARAN}

\subsection{Kesimpulan}

Dari hasil penelitian dan pembahasan di atas, maka dapat ditarik kesimpulan sebagai berikut :

1. Profitabilitas, Solvabilitas, Ukuran Perusahaan dan Likuiditas secara simultan berpengaruh signifikan terhadap Audit Delay perusahaan-perusahaan subsekstor makanan dan minuman BEI

2. Profitabilitas secara parsial berpengaruh negative namun signifikan terhadap Audit Delay perusahaanperusahaan subsekstor makanan dan minuman BEI

3. Solvabilitas secara parsial berpengaruh negative namun signifikan terhadap Audit Delay perusahaanperusahaan subsekstor makanan dan minuman BEI

4. Ukuran Perusahan secara parsial berpengaruh signifikan terhadap Audit Delay perusahaan-perusahaan subsekstor makanan dan minuman BEI

5. Likuiditas secara parsial berpengaruh negative namun signifikan terhadap Audit Delay perusahaanperusahaan subsekstor makanan dan minuman BEI

\subsection{Saran}

Berdasarkan hasil penelitian dan pembahasan di atas, maka penulis memberi saran sebagai berikut

1. Hasil penelitian dapat digunakan untuk pengembangan ilmu pengetahuan akuntansi khususnya untuk Profitabilitas, Solvabilitas, Ukuran Perusahan dan Likuiditas serta Audit Delay

2. Dalam penelitian ini yang diteliti hanya terbatas pada pengaruh Profitabilitas, Solvabilitas, Ukuran Perusahan, Likuiditas dan Audit Delay di Perusahaan-perusahaan makanan dan minuman BEI. Sedangkan faktor-faktor lain yang juga berpengaruh terhadap Audit Delay yang belum diungkap berapa besar pengaruhnya, semoga pada penelitian selanjutnya dapat membahas faktor-faktor lain yang belum diteliti dalam penelitian ini., misalnya ukuran kantor akuntan public 


\section{DAFTAR PUSTAKA}

Abdul Halim. (2005). Analisis Investasi. Salemba Empat, Jakarta.

Agnes Sawir. 2004. Analisis Kinerja Keuangan dan Perencanaan Keuangan Perusahaan, Jakarta : PT. Gramedia Pustaka Utama

Agoes, Sukrisno. 2004. Auditing (Pemeriksaan Akuntan) oleh Kantor AkuntanPublik. Edisi Ketiga. Penerbit Fakultas Ekonomi Universitas Trisakti.

Almilia, Luciana Spica dan Lucas Setiady. 2006. "Faktor-Faktor yang Mempengaruhi Penyelesaian dan Penyajian Laporan Keuangan pada Perusahaan yang Terdaftar di BEJ”. Seminar Nasional Good Corporate Governance. Universitas Trisakti Jakarta, hal 1-28

Arens, Alvin A. Elder, Randal J. and Beasley, Mark S. 2008. Auditing dan Jasa Assurance : Pendekatan Terintegrasi Jilid 1. Edisi 12. Salemba Empat. Jakarta

Boynton, Johnson, dan Kell, dialihbahasakan oleh Ichsan Setiyo Budi dan Herman Wibowo, 2003, Modern Auditing, Jilid II, Edisi Ketujuh, Jakarta: Erlangga

Carslaw, C.A.P.N. dan S.E. Kaplan. 1991 ”An Examination of Audit Delay: Further Evidence from New Zealand", Accounting and Business Research 22(85):21-32.

Chambers, Anne E and Stephen H Penman. 1984. "The Timeliness of Reporting and the stock Price Reaction to earning Announcements". Journal of Accounting Research (204-220)

Davis, Ralph C., 2002, Fundamental Of Top Management, Tokyo, Penerbit: Kogakusha Company Limited

Dyer J C, and Mc Hugh. 1975. “ The Timeliness of the Australian annual report”. Journal of Accounting Research,13(3):204-219

Givoly, D. dan Palmon, D. 1982. Timeliness of Annual Earning Announcements: Some Empirical Evidence. The Accounting Review, Vol.LVII., No,3.

Halim, Varianada. 2000. "Faktor-Faktor Yang Mempengaruhi Audit Delay: Studi Empiris Perusahaan-perusahaan di Bursa Efek Jakarta", Jurnal Bisnis dan Akuntansi 2(1):63-75.

Harahap, Sofyan, 2001. Sistem Pengawasan Manajemen, Penerbit Quantum, Jakarta

Hilmi, Utari dan Syaiful Ali. 2008. "Analisis Faktor-Faktor Yang Memepengaruhi Ketepatan Waktu Penyampaian Laporan Keuangan (Studi Empiris pada Perusahaan-perusahaan yang Terdaftar di BEJ)”. Simposium Nasional Akuntansi XI Ikatan Akuntan Indonesia

Jensen, M. C and Meckling, W.H. 1976. Theory of the Firm : Managerial Behavior,Agency Costs and Ownership Structure . Journal of Financial Economics, Oktober, 1976, V. 3, No. 4, pp. 305-360. Avalaible from: http://papers.ssrn.com

Messier, William F., Jr. 2003. Auditing \& Assurance Services A Systematic Approach. Prentice Hall, Inc. Mulyadi. 2002. Auditing. Jakarta: Salemba Empat.

Mursyidi. (2010). Akuntansi Dasar. Bogor: Ghalia Indonesia

Owusu-Ansah, Stephen. 2000. "Timeliness of Corporate Financial Reporting in Emerging Capital Market: Empirical Evidence from The Zimbabwe Stock Exchange”. Journal Accounting and Business Research. Vol.30. No.3. pp.241-254.

Paz, Lawrence W.1998. Auditing Integrated Control Systems. Boston. Kent Publishing

Petronila T.A dan Mukhlasin, 2003, Pengaruh Profitabilitas Perusahaan Terhadap Ketepatan Waktu Pelaporan Keuangan dengan Opini Audit

Rachmawati, Sistya. 2008. Pengaruh Faktor Internal dan Eksternal Perusahaan terhadap Audit Delay dan Timeliness. Jurnal Akuntansi dan Keuangan. Vol. 10, No. 1, Mei, hal 347-356.

Subekti, Imam. dan N.W. Widiyanti. 2004. "Faktor-Faktor Yang Berpengaruh Terhadap Audit Delay di Indonesia", Simposium Nasional Akuntansi VII:991-1002

Suwardjono, 2005. Teori Akuntansi: Perekayasaan Pelaporan Keuangan (Edisi III). Yogyakarta: BPFE

Ukago, Kristianus. 2004. Faktor-Faktor yang Berpengaruh Terhadap Ketepatan Waktu Pelaporan Keuangan Bukti Empiris Emiten di Bursa Efek Jakarta.

Weston, J. Fred., dan Thomas E. Copeland, 1995, Manajemen Keuangan, Edisi 8. Jilid 1. Alih bahasa: Jaka Wasana dan Kirbrandoko. Gelora Aksara Pratama, Jakarta 